\title{
THE PRESIDENTIAL PERSONA PARADOX OF BARACK OBAMA: MAN OF PEACE OR WAR PRESIDENT?
}

\author{
SALLY TOTMAN AND MAT HARDY
}

\section{ABSTRACT}

On a wave of hope and rousing talk of building global bridges, President Barack Obama won office in 2008, in part on a pledge to end the wars in Afghanistan and Iraq and to close the Guantanamo Bay detention facility. In contrast to his predecessor, who launched America into long, costly and ineffectual wars, Obama was seen to be more of a dove than a hawk. However, at the end of his two-term tenure America has been in a state of foreign belligerence for all eight years, making Obama the longest serving U.S. war president in history.

The political persona of Obama as a dove originated with his opposition to the 2003 intervention in Iraq while he was still a senator. This was then cemented early in his presidency with his 2009 speech in Cairo, which seemed to signal a profound and optimistic realignment of America's intentions towards the Middle East and its peoples. This speech was a watershed in defining his political persona and was instrumental in his being the only U.S. president to be awarded a Nobel Peace Prize while still in office. However, during his term the underlying political landscape of the Middle East changed significantly, with the withdrawal from then return to Iraq, the nuclear agreement with Iran, the increasingly chaotic legacy of the Arab Spring, the continued impasse of the Israel-Palestinian peace, the disintegration of Yemen and Libya and the rise of the Islamic State as the new threat in the political vacuum of northern Iraq and eastern Syria, and a resurgent Russian role in the region. All of these have provided novel challenges to Washington and a president attempting to live up to the positivity of his early days in office.

At the end of his presidency Obama is faced with a public burned by the disappointments of the Iraq and Afghanistan campaigns and the new entanglements in the Middle East. This paper seeks to offer insights into the juxtaposition of Obama's political persona and reality, as well as exploring what his political legacy might really be.

\section{KEY WORDS}

Political Persona; Political Legacy; Middle East; Obama; United States

On a wave of hope and rousing talk of building global bridges, President Barack Obama won office in 2008, in part on a pledge to end the wars in Afghanistan and Iraq and to close the Guantanamo Bay detention facility. In contrast to his predecessor, who launched America into long, costly and ineffectual wars, Obama was seen to be more of a dove than a hawk and aspirations were high that he would steer America and the world on a more positive trajectory. 
This political persona of Obama as a dove originated with his opposition to the 2003 intervention in Iraq while he was still a senator and was cemented early in his presidency with his 2009 speech in Cairo, which seemed to signal a profound and optimistic realignment of America's intentions towards the Middle East and its peoples. This speech was a watershed in defining his political persona and was instrumental in his being the only U.S. president to be awarded a Nobel Peace Prize while still in office. But has this early persona been justified over the eight years of his office?

There is a long and profuse academic history of examining political leaders and the way they shape their public images. Academics such as John Street and W. Lance Bennett have written extensively in this area, looking at everything from how leaders use story-telling and speeches as part of their image construction to the way news is framed by journalists and the mass media to support (or undermine) their image management. The consensus of such research demonstrates that the character of political figures is a constructed fiction, with the persona of all political figures fabricated and contrived for political gain. What is lacking in most academic examinations of political persona and its construction is an in-depth study of how a leader's persona as viewed by the public can differ from the reality of their actions (or inactions). This paper is not concerned with re-hashing the academic literature detailing how political personas are constructed, but rather with undertaking an in-depth analysis of how the constructed persona of a political leader can withstand the realities of politics to build a legacy and reputation far removed from their actual performance.

The nature of a politician's legacy becomes important to them (and commentators) towards the end of their career. For American presidents, their interaction with the Middle East region is often seen as a hallmark of their tenure. Did they handle the challenges of the region well? Did they have a positive effect on the problems and tensions therein? Was their reign peaceful or dogged by conflict? For Jimmy Carter, it was the Iranian Revolution and subsequent hostage crisis that hobbled his presidency right to the end. Ronald Reagan's Lebanese and Libyan entanglements and the Iran-Contra Affair were significant episodes in his two terms of office. Both Bush Senior and Junior are indelibly linked with conflicts with Iraq. Bill Clinton's handshakes on progress between Israel and Palestine were seen as momentous products of his diplomatic skill. Indeed, since the 'Eisenhower Doctrine' of 1957, the importance of the Middle East to America has become a truism for presidents and their success or failure in that region becomes an inevitable part of their legacy.

Barack Obama will fare no differently in this regard. Within a few weeks of taking office in 2009 President Obama had signalled that his administration would place an emphasis on interaction between America and the Islamic world, and the Middle East in particular. As part of his first overseas trip as president, Obama visited Turkey in early April before flying on to Iraq. In a forerunner of his more well-known Cairo speech, Obama addressed the Turkish parliament:

I know there have been difficulties these last few years. I know that the trust that binds the United States and Turkey has been strained, and I know that strain is shared in many places where the Muslim faith is practiced. So let me say this as clearly as I can: The United States is not, and will never be, at war with Islam. (Applause.) In fact, our partnership with the Muslim world is critical not just in rolling back the violent ideologies that people of all faiths reject, but also to strengthen opportunity for all its people. I also want to be clear that America's relationship with the Muslim community, the Muslim world, cannot, and will not, just be based upon opposition to terrorism. We seek broader engagement based on mutual interest and mutual 
respect....There's an old Turkish proverb: "You cannot put out fire with flames." America knows this. Turkey knows this. There's some who must be met by force, they will not compromise. But force alone cannot solve our problems, and it is no alternative to extremism. The future must belong to those who create, not those who destroy. That is the future we must work for, and we must work for it together. (Remarks By President Obama To The Turkish Parliament)

In this speech, and his Cairo version in June 2009, Obama outlined his vision for a new era in U.S.-Muslim relations. His Kenyan heritage and Indonesian residency were mentioned but it is telling that when he gave specific examples of what he was aiming for in this new relationship with Islam, the Middle East and Afghanistan/Pakistan were the emphasis. The Muslim world beyond those strategic interests was mentioned only generically. In this sense, Obama's new era was very much concerned with the same set of geographical preoccupations as most of his predecessors. However, in contrast to the interactions that George W. Bush had overseen, Obama attempted to couch these interests in peaceful terms in his speeches. This was in line with his dove-like persona and 'new broom' image. Key points of these early presentations included:

Iraq: Disentangling America from Iraq was a key plank in Obama's election platform. Dissatisfaction with the years of loss there and the seemingly unending quagmire was rising and Obama made it clear that America's military presence was coming to an end: "America has a dual responsibility: to help Iraq forge a better future-and to leave Iraq to Iraqis" (Remarks by the President on a New Beginning).

Israel-Palestine: The stalled Road Map and the intransigence of the parties in the peace process was something Obama, like so many presidents before him, aimed to address: "I intend to personally pursue this outcome with all the patience and dedication that the task requires... All of us have a responsibility to work for the day when the mothers of Israelis and Palestinians can see their children grow up without fear..." (Remarks by the President on a New Beginning).

Iran: Seen as an implacable enemy to U.S. interests since 1979, Iran and its nuclear potential was third on Obama's list of priorities in his Cairo speech: "I've made it clear to Iran's leaders and people that my country is prepared to move forward...it is clear to all concerned that when it comes to nuclear weapons, we have reached a decisive point. This is not simply about America's interests. It's about preventing a nuclear arms race in the Middle East that could lead this region and the world down a hugely dangerous path" (Remarks by the President on a New Beginning).

Terrorism: The presence within, and export of violent ideologies from, the Middle East had been a bugbear for American presidents since the days of Ronald Reagan. Linked with concerns such as Iran and an unstable Iraq, Obama's early speeches pre-date the rise of the Islamic State and instead focus on al-Qaeda and those localities that provided haven and support for the group. It is notable that the Cairo speech did not include a single mention of the word 'terrorism', which some interpreted as a means of distancing America's vision of the Middle East from that of the Bush era and the conflation of the War on Terror with a broader war on Islam.

Democratisation and freedom: Strong democratic institutions, personal freedoms and the rights of women also figured in Obama's avowed policies. However, burned by the bungled attempts to impose democracy on Iraq, Obama's remarks were shaped by a sense of Middle 
Eastern realpolitik: "there are some who advocate for democracy only when they're out of power; once in power, they are ruthless in suppressing the rights of others...You must maintain your power through consent, not coercion; you must respect the rights of minorities, and participate with a spirit of tolerance and compromise; you must place the interests of your people and the legitimate workings of the political process above your party. Without these ingredients, elections alone do not make true democracy" (Remarks by the President on a New Beginning). Such observations would become ironic given the next few years and the journey of the Arab Spring, particularly in Egypt itself.

Such ambitions were received with general positivity in the Middle East and the West. The title of the Cairo speech-A New Beginning - was taken by optimists at face value. Reactions in the Middle East were positive, both from leaders in the region and commentators. At the other end of the spectrum were those who saw the speech as empty rhetoric or who were cognizant of the extreme difficulties such lofty aspirations would face in the realities of the Middle Eastern political system. Further still along the continuum were those abroad and at home who were outraged by Obama's words and saw them as a patronising lecture, a betrayal of Israel, or a capitulation of America's interests. For example, House Republican Leader in Congress, John Boehner, said "[Obama] continues to say he will sit down with the Iranians without any preconditions, I just think that that puts us in a position where America looks weak in the eyes of their rulers" (BBC).

The wider world was even more approving of Obama's diplomatic overtures. World opinion of Obama has been consistently high over the years (As Obama Years Draw to Close, President and U.S. Seen Favorably in Europe and Asia). In October 2009, after only a few months in office, he was awarded the Nobel Peace Prize for his "extraordinary efforts to strengthen international diplomacy and cooperation between peoples." The Committee placed emphasis on Obama's "vision of and work for a world without nuclear weapons" (Norwegian Nobel Committee). This made Obama only the fourth American President so honoured. Moreover, the other three laureates (Teddy Roosevelt, Woodrow Wilson, and Jimmy Carter) were all recognised towards the end (or after) their terms and for substantial actual achievements.

But it was not 'the Muslim world' or Norwegian intellectuals who elected Obama to two terms of office. It was American voters who installed him in the 2008 elections and then opted to double down in 2012. Measuring their reactions to their president is critical, not just for his tenure and legacy, but also if we are to understand what role Middle Eastern foreign policy has in the mind of the American public and whether it has a substantive impact on image and reputation. Whilst lofty foreign policy goals such as solving the Israel-Palestine deadlock or bringing democracy to Iraq may fascinate observers, do such ambitions 'play in Peoria'? Does success or failure in the world's great political challenges have any real impact on voters or the projected persona of a president?

\section{PUBLIC OPINION AND OBAMA'S ACTIONS}

Given the approbation that his 2009 speeches received, it is worth examining how the aspirations Obama expressed measure up to the subsequent years of actions. By comparing some of the same points he raised then and assessing what actually ensued, the contradictions between Obama's benign image and his real legacy are illustrated. Data on public opinion relating to these events is offered as a means of exploring why his actions have had little impact on a largely positive public persona.

The scrutiny of public opinion polls as a catalyst for examining U.S. foreign policy is long established (Dieck; Foyle; Mueller). There are various models and hypotheses regarding the 
extent to which public opinion influences foreign policy and presidential direction. However, public opinion can be particularly important when it comes to committing American forces to conflict and what the nature of such an intervention might involve (Dieck). For example, whilst the public might favour some form of intervention, support for full scale ground occupations may be limited compared to support for aerial campaigns or peace-keeping type deployments. Ignoring public opinion is not uncommon for presidents when interacting with the Middle East, but it has its pitfalls and failing to heed the mood of the public may have repercussions for longterm approval. Public opinion polls can therefore be critical to the management of political persona and long-term legacy formation.

There is a long tradition in Social Sciences of using public opinion data (Donsbach and Traugott) for analysing political support and this paper draws upon that established foundation. Our intention is not to present and debate the literature surrounding this sub-field of Political Science but to instead focus on the case study of President Obama and how his actions in the Middle East are reflected in public opinion polling. A myriad of polls and question sets will be generated during any American president's term, so in examining Obama's eight years of Middle East interaction this paper will focus mainly on those produced by the Pew Research Center. As a non-partisan entity that specialises in U.S. public opinion, Pew has a strong reputation for credibility and conducts large sample polls via established methodologies.

By presenting the relationship between words, deeds, and public perceptions, this paper will attempt to demonstrate that for Obama the realities of the Middle East have not managed to tarnish the fantasies of his image.

\section{Iran}

Arguably the biggest foreign success of Obama's presidency has been involvement in the Joint Comprehensive Plan of Action (JCPOA) deal reached with Iran over the Islamic Republic's nuclear ambitions. Addressing years of uncertainty and hostility over Iran's nuclear activities, Obama described the JCPOA as "the most consequential foreign policy debate that our country has had since the invasion of Iraq" (Remarks by the President on the Iran Nuclear Deal). Opening the path to further dialogue with Iran and being potentially the biggest positive change in U.S. relationships with the region in decades, the afterglow of the signing was short-lived for Obama and the American public.

Strident criticism of the JCPOA from Republicans and pro-Israel voices as a 'green light' to Iranian aspirations for a nuclear weapons program quickly cast the deal as a humiliating surrender for America. Despite the very detailed explanations from the White House as to the severity of the inspections regime, a Pew survey found that only $33 \%$ of the public approved of the agreement when it was announced, while $45 \%$ disapproved and $22 \%$ had no opinion (Support for Iran Nuclear Agreement Falls). That is, two thirds of the American public either disapproved or did not care about the JCPOA. Approval dropped to $21 \%$ in the following six weeks. Similar levels of approval were exhibited in other polls, though results varied according to how much the respondents had heard about the deal or had it explained to them. Generally, those more informed about the JCPOA were more likely to be approving. Those who knew little or nothing about the deal were more reflexive in their disapproval.

Distrust of Iran and, by extension, American leaders who make deals with that nation, is apparently endemic in the U.S. In the most recent annual survey (2015) of U.S. public opinion on Iran only $14 \%$ of Americans exhibited a favourable opinion of the Islamic Republic, down from only a marginally better score of $21 \%$ when Obama took office in 2009 (Opinion of Iran. Do you 
have a favorable or unfavorable view of Iran?). So predictable is this mistrust, Iran is one of only three countries that Pew seeks favourable/unfavourable opinions on annually (the others being Russia and China).

Given this data, it would seem any president setting his course towards agreement with Iran cannot expect to be applauded for it. The majority of American voters either have no interest in such lofty foreign policy goals or else see such deals as a zero-sum game, where American interests are harmed by any handshake. The paradox here is that Obama may have suffered a public opinion loss for engaging in a deal that actually furthered the cause of peace.

\section{Iraq and intervention in the Middle East}

The long involvement with Iraq stemming from the 2003 invasion has not created a positive impression among Americans or enamoured them of military entanglement in the Middle East. With the benefit of hindsight, by early 2014 only $38 \%$ of Americans felt that the historic Iraq intervention had been the right course of action and 52\% felt that America had "mostly failed" to achieve its goals in that country (Drake, More Americans say U.S. failed to achieve its goals in Iraq). Importantly, these Pew figures show a marked decline during Obama's presidency, indicating that voters (and particularly Democrat voters) were unenthusiastic about further American involvement there. Obama's 2009 pledge in Cairo to leave Iraq to the Iraqis would have been in tune with such sentiment.

The chariness over Middle East intervention was evident during the crises in Libya and Syria. In the chaos of the Arab Spring, only 27\% of Americans polled in March 2011 felt that the U.S. had a responsibility to act in Libya (Public Says U.S. Does Not Have Responsibility to Act in Syria). However, $50 \%$ approved of the U.S. participation in airstrikes on Gadhafi's forces as an appropriate course of action. The relatively swift deposition of the dictatorship meant that by September 2011 polls showed 49\% of the U.S. public felt approval for Obama's actions in Libya (Libya: Steady Views, Declining Interest).

The dilemma posed by this sort of feedback is that the American public may only be supportive of quick, clean air campaigns that are rapidly successful. Even then, majority approval is not in evidence. As with the Iran nuclear negotiations, support for intervention is higher among those who are bigger consumers of news coverage concerning the Middle East. This demographic is quite small, though. In September 2011, only 17\% of Americans polled reported that they had followed news from Libya closely in the week before they were polled, and in this group 63\% felt that airstrikes were the appropriate recourse (Libya: Steady Views, Declining Interest). The vast majority of Americans were not following events in Libya and had more mixed feelings about intervening (35\% approval) or no opinion at all (24\%).

Remote warfare as the publicly preferred manner of intervention is evidenced by other polls during Obama's presidency, with backing for drone strikes to combat terrorists abroad trending in the mid-50 percent region (Drake, Obama and drone strikes: Support but questions at home, opposition abroad; Public Continues to Back U.S. Drone Attacks). Under Obama, the use of drone strikes has seen a ten-fold increase in comparison to the George W. Bush years, with nearly 3,500 people killed (Zenko). Through this clandestine war, Obama has managed to conduct a ruthless and far-ranging extermination campaign against potential enemies, whilst at the same time keeping on the right side of public opinion and avoid tarnishing his anti-war image. 
However, public reluctance for overt actions in the region posed challenges for Obama's responses to the Syrian crisis. Fettered by the UN Security Council deadlock, the same pathways of coalition airstrikes used in Libya were not available in Syria. Public opinion too was on par with that towards intervention in Libya. In March 2012, only 25\% of respondents felt America had a responsibility to act in Syria, and by December 2012 this was still only at $27 \%$ (Public Says U.S. Does Not Have Responsibility to Act in Syria). Obama's setting of a "red line" in Syria over chemical weapons use and then failing to commit to war when this line was crossed was something of a reputational loss internationally, but domestic public opinion was still ambivalent. The mixed feedback generated a muddled approach to Syria that deepened the crisis in intensity and duration but kept Obama clear of being seen as a warmonger.

Unfortunately, the repercussions of this sideline position on Syria would then emerge in Iraq.

Having left "Iraq to the Iraqis" for a while, the ground taken by the Islamic State (IS) mid-2014 invoked the other clause in Obama's speech: "to help Iraq forge a better future." The failure of the increasingly autocratic Maliki regime to foster unity in Iraq was also part of the problem and in discord with Obama's rhetoric about democracy and pluralism. America's investment in Iraq, the need to secure the country and placate regional allies meant that Washington felt the need to act. Commentators also quoted the 'Pottery Barn Rule' (You break it. You own it), implying that the U.S. had a moral obligation to shore up the country that their intervention had arguably shattered.

The American public, however, did not see it that way. A 55\% majority felt that the U.S. had no responsibility to act in Iraq, with only 39\% supporting intervention (Most Think the U.S. Has No Responsibility To Act in Iraq). This was despite $45 \%$ of respondents reporting they had heard 'a lot' about the violence in Iraq and the takeover of large parts of the country by the Islamic State forces. By way of contrast though, 57\% of Americans said that same week that they had heard a lot about the recent influx of illegally immigrating unaccompanied minors across the U.S.-Mexican border. The comparative awareness between domestic 'threat' and Middle Eastern crisis is stark, again showing that big picture geo-strategic events are of less concern to voters than domestic issues.

As the crisis in Iraq deepened, however, support for the fight against IS increased. By the start of 2015, 63\% of those surveyed said they approved of a "campaign" against Islamic militants in Iraq and Syria. The issue of what sort of campaign was a little more divisive, with a fairly even split between those who did (47\%) or did not (49\%) support the commitment of U.S. ground forces to this action when polled in February 2015. This was still a marked increase from October 2014, where respondents to the same question were more clearly opposed to U.S. ground intervention (only 39\% approval versus 55\% disapproval) (Growing Support for Campaign Against ISIS - and Possible Use of U.S. Ground Troops).

This indecision over ground troops is also reflected in attitudes towards how best to deal with violent extremism around the world. Democrat voters are markedly wary of the use of military force as a solution. In the February 2015 survey, two thirds of Democrat supporters felt that "relying too much on military force to defeat terrorism creates hatred that leads to more terrorism." Only $22 \%$ of Republican voters held the same opinion. Concerns over the effectiveness and duration of intervention were also expressed, with a fairly even split between respondents' "biggest concern" being that either the U.S. would not go far enough to stop the militants (49\%) or that it would go too far in getting involved in the situation. The spectre of the Iraq occupation is evident here. 
Such ambivalence posed a problem for Obama. Not getting involved in Syria early in the uprising was reflective of the Iraq experience. Yet the lack of response allowed a civil war to sputter along and irredeemably fracture Syrian society. When IS grew out of these cracks and marched towards Baghdad, Obama's slow and piecemeal re-commitment to Iraq was a product of the electoral tightrope he had to walk. Voters did not want to see a large scale "Iraq 2.0" deployment (Mathes). The choice of an air campaign and the increased backing of local militias is also a classic Democrat option, despite the probable ineffectiveness of this strategy to definitively defeat IS. Having inherited the Iraq predicament from his predecessor, Obama had to be wary about saddling the next Democratic candidate with a newer version; especially when the majority of the voting public seem opposed to such adventures. Low-key action was the solution, notwithstanding the fact that Obama was actually re-committing to protracted conflict in the very nation that he had lambasted his predecessor's martial involvement in.

\section{Israel-Palestine}

If there is a chimera among American presidential ambitions in the Middle East, it is in seeking a lasting solution to the Israel-Palestine issue. From Bill Clinton's grandiose Rose Garden moment with Yasser Arafat and Yitzhak Rabin, through George W. Bush's Annapolis Conference, to Obama's own 'personal pursuit' of peace, many presidents have foundered on the shoals of this dispute. Like a grail quest, this elusive objective is pursued almost out of custom. However, the reality of public opinion indicates that voters do not really care about this most intractable of world problems. Indeed, any solution that seems to disadvantage Israel-as any compromise surely must—could actually be a handicap for a president.

Opinion polls show consistent favour for Israel among Americans. When asked with whom they most sympathise with, or favour, in the conflict, steady figures of around $60-72 \%$ have indicated Israel (More Express Sympathy for Israel than the Palestinians; Saad). Favour for Palestinians hovers around the high teens to low 20 percent mark. These trends have been consistent throughout Obama's presidency, and for years beforehand. There is little doubt that American public opinion is firmly on the side of Israel. While Democrats are traditionally less supportive in this regard, it would still be foolish for any president to pursue a line of policy that could be construed as detrimental in this area. Despite Obama and Benjamin Netanyahu's worsening relationship over the years, the Israeli prime minister can count seemingly on the support of the American public.

This is borne out by Obama's distinct lack of action on the Israel-Palestine impasse. Despite saying he would pursue progress with "patience and dedication," Obama has never significantly challenged Netanyahu's intransigence. Solving this problem is, of course, not as simple as two leaders working things out between them. But Palestinian hopes for viable statehood have diminished significantly under Obama's tenure. This is again at odds with his benevolent image.

\section{CONCLUSION}

Throughout his two terms, Obama's overall approval rating has fluctuated without any evident link with his policies towards the Middle East. Despite a multitude of crises in the region, these fluctuations have stayed within a narrower range than most of his post-World War II predecessors but follow broadly the same trend lines when mapped against years of tenure. High and low points in Obama's presidential approval figures have more clearly been the result of domestic affairs such as the passing of Obamacare or budgetary deadlocks. 
Regardless of the emphasis that is placed upon U.S. foreign policy towards the Middle East by many academics and commentators, interactions there have no real resonance with the American public. Indeed, foreign policy as a whole is of no great interest in comparison to domestic issues. Most Americans do not closely follow events in the Middle East, and even those who do are not overwhelmingly approving of too much intervention there. This confusion and ambivalence about the Middle East on the part of the American public is demonstrated in a December 2015 poll where 30\% of respondents indicated support for bombing Agrabah, the fictional Middle Eastern city in Disney's film Aladdin (Public Policy Polling).

President Obama's successor would do well to heed these findings. Solving Middle East peace dilemmas is a lofty ambition, but 'all politics is local'. The American public does not express a strong interest in Middle Eastern affairs and they do not want their leaders to become involved in conflict there or risk national prestige in compromises. In his eight years of office, President Barack Obama has been relatively successful in treading this line, despite the fact that he has been involved in various states of belligerency for all the days of his presidency. In May 2016, he passed the milestone of having been at war for longer than any other U.S. president in history (Landler). He is unlikely to be popularly remembered in this manner though, with pundits instead focussing on other aspects of his presidency, such as domestic reforms and his status as a ground-breaker for people of colour (New York Magazine).

In the Middle East the result is that Obama's actions (or relative lack of them) have left little legacy, except for the deepening of problems that were already germinating when he was sworn in. Despite his good intentions and the hopes of the Nobel Prize Committee there has been no significant gains in Middle East peace during Obama's White House stay. This may be lamentable, but from the perspective of public opinion, was a politically shrewd strategy.

Obama himself seems to find the reasons for the Nobel Prize he was awarded mystifying. Appearing on the Late Show With Stephen Colbert in October 2016, President Obama was asked what he received the Nobel Peace Prize for and he answered "to be honest, I still don't know." Despite being a satirical interview, it is perhaps an insight into the fact that even Obama realises his political reputation and recognition does not correlate with his actual achievements.

Marshall and Barbour argue that today we see the "false nature of presentation in politics" but it appears that for President Obama the persona he has constructed as a man of peace withstands all comparisons with reality. This paradox might be his greatest achievement and real political legacy.

\section{WORKS CITED}

BBC. Reaction: Obama's Cairo speech. Web. 4 June 2009.

Bennett, W Lance. News: The Politics of Illusion. Tenth Edition. Chicago: University Of Chicago Press, 2016. Print.

Dieck, Helene. "Public Opinion and U.S. Military Interventions: The President's Room for Maneuver after the Cold War." Conference Papers -- American Political Science Association (2010): 1-33.

Donsbach, Wolfgang and Michael W Traugott. The SAGE Handbook of Public Opinion Research. London: SAGE, 2008. Print.

Drake, Bruce. More Americans say U.S. failed to achieve its goals in Iraq. Web. 12 June 2014. 
---. Obama and drone strikes: Support but questions at home, opposition abroad. Web. 24 May 2013.

Foyle, Douglas C. Counting the Public In: Presidents, Public Opinion, and Foreign Policy. New York: Columbia University Press, 1999. Print.

Landler, Mark. For Obama, an Unexpected Legacy of Two Full Terms at War. Web. 14 May 2016. Marshall, P David, and Kim Barbour. "Making Intellectual Room For Persona Studies: A New Consciousness And A Shifted Perspective." Persona Studies 1.1 (2015): 1-12. Web.

Mathes, Michael. US Congress wary of greenlighting 'Iraq 2.0'. Web. 12 September 2014.

Mueller, John. War, Presidents and Public Opinion. New York: Wiley, 1973. Print.

New York Magazine. 53 Historians Weigh In on Barack Obama's Legacy. Web. 11 January 2015.

Norwegian Nobel Committee. The Nobel Peace Prize for 2009. 2009. Press release.

Obama, Barack. Remarks By President Obama To The Turkish Parliament. 2009. Press release.

---. Remarks by the President on a New Beginning. 2009. Press release.

---. Remarks by the President on the Iran Nuclear Deal. 2015. Press release.

Pew Research Center. As Obama Years Draw to Close, President and U.S. Seen Favorably in Europe and Asia. Web. 29 June 2016.

---. Growing Support for Campaign Against ISIS - and Possible Use of U.S. Ground Troops. Web. 24 February 2015.

---. Libya: Steady Views, Declining Interest. Web. 8 September 2011.

---. More Express Sympathy for Israel than the Palestinians. Web. 28 August 2014.

---. Most Think the U.S. Has No Responsibility To Act in Iraq. Web. 18 July 2014.

---. Opinion of Iran. Do you have a favorable or unfavorable view of Iran? Web. 2015.

---. Public Continues to Back U.S. Drone Attacks. Web. 28 May 2015.

---. Public Says U.S. Does Not Have Responsibility to Act in Syria. Web. 14 December 2012.

---. Support for Iran Nuclear Agreement Falls. Web. 8 September 2015.

Public Policy Polling. Trump Lead Grows Nationally; 41\% of His Voters Want to Bomb Country From Aladdin; Clinton Maintains Big Lead. Web. 18 December 2015.

Saad, Lydia. Seven in 10 Americans Continue to View Israel Favorably. Web. 23 February 2015.

"Stephen Colbert Helps President Obama Polish His Résumé On The Late Show." CBS, 18 October 2016. Television.

Street, John. "The Celebrity Politician: Political style and popular culture." Media and the restyling of politics: consumerism, celebrity and cynicism, edited by John Corner and Dick Pels, London: SAGE, 2003, 85 -89. Print.

Zenko, Micah. Obama's Embrace of Drone Strikes Will Be a Lasting Legacy. Web. 12 January 2016. 